Review

\title{
Food Neophobia or Distrust of Novelties? Exploring Consumers' Attitudes toward GMOs, Insects and Cultured Meat
}

\author{
Elena Faccio *(1) and Lucrezia Guiotto Nai Fovino \\ Department of Philosophy, Sociology, Education and Applied Psychology, University of Padua, Via Venezia 14, \\ 35131 Padua, Italy; lucrezia.guiottonaifovino@gmail.com \\ * Correspondence: elena.faccio@unipd.it; Tel.: +339-04-9827-7421
}

Received: 7 September 2019; Accepted: 12 October 2019; Published: 19 October 2019

\begin{abstract}
The food industry is constantly challenged to find new ideas to satisfy the increasingly specific consumer demand. However, innovative food products do not always become part of consumption habits or create a market. One of the major sources of resistance to novelty lies in the attitude of the consumer, who in many cases may be suspicious or hostile as a result of specific ideologies, overly attached to tradition, or affected by neophobia. This paper analyzes the construct of food neophobia (the "unwillingness to try new foods") in its phenomenology and its actual power to explain hostility to innovation in the agri-food sector. The limits of the concept, which is not always sufficient to shed light on the many reasons that could underlie the rejection of certain foods, will also be discussed. In addition, we review the recent literature on Europeans' attitude toward novel foods and innovation including Genetically modified organisms (GMOs), cultivated meat and insects as food. This literature reveals a number of paradoxes in consumers' behavior, and in the many complex conditions underpinning the success of innovation in food production. These conditions can only be understood by reconstructing the meanings consumers assign to food, and are often embedded in larger social and political frameworks.
\end{abstract}

Keywords: food neophobia; food innovation; resistance to novel food; consumer attitudes; GMO; cultured meat; insect consumption

\section{Introduction}

With a global population expected to reach 9 or even 10 billion by the year 2050 and natural resources for food production already scarce in many parts of the world [1,2], humankind is facing a serious challenge: how can we feed everybody? The scientific community has presented various strategies for using current resources to increase the sustainability of food production without using more agricultural land. The main strategies are dietary changes to plant based alternatives, improvements in technology and management and reduction in food waste (e.g., [3,4]). These measures call for changes on the part of both industries/retailers and people involved as customers and as scientists. We investigate several current trends in European thinking about food, seeking to link the various factors involved in consumer acceptance of new dietary elements that are of interest from a sustainability standpoint.

The process of industry innovation is closely linked to the availability of new products on the market. To create consumer demand, new food product launches must combine technological innovation with a series of social and environmental changes, large and small [5]. Indeed, innovation is born from the continuous interaction between the food industry and the institutional and social context in which it operates: it is an opportunity to meet the needs of citizen-consumers, while also responding 
to emerging social challenges such as environmental sustainability and animal welfare [6-10]. By contrast, research on market trends in food choices shows that there is some resistance to innovations and confirms the stability of decision-making processes that proceed from inertia. Consumers themselves are the biggest obstacle to innovation in the food sector. By definition, an innovative food entails a change from known characteristics, and this tends to clash with habit-bound consumer behavior. This makes many innovations in the agri-food sector incremental rather than radical [7].

As the literature shows, however, it is not always easy to distinguish between cases where consumers' resistance can be circumvented by improving specific product characteristics [11], and cases where resistance is more deeply rooted, as it is linked to specific ideologies about food and is thus not readily overcome. Accordingly, it can be useful to analyze the various facets of food neophobia, or "human unwillingness to consume unfamiliar food" [12], which cuts across the technological challenges now facing the European food industry. As food neophobia can be elicited by a wide range of foods in an increasingly demanding and specialized food market, it can be a major obstacle for producers and consumers alike. Knowing which products are generally associated with neophobia, and which details of the products trigger it is important because it can provide the industry with insight into how to overcome or curb sales resistance. It is equally important to understand whether food neophobia is just an extreme situation, a clinical condition consisting of unjustified rejection of unfamiliar food products, with no logical justification for the adverse emotional reaction of disgust and refusal, or whether it reveals an ingrained attitude that may extend to a wide range of situations.

We will take a closer look at neophobia in order to analyze the construct, understand the instruments whereby it is measured, and explore the situations to which it applies. In fact, neophobia is marked by an underlying "mistrust" of foods that have never been tasted, and is probably linked to a pre-coding of food in a rigid visual schema. Above all, however, it is associated with food's olfactory impact, which jeopardizes its acceptability [10]. This clinically extreme condition mainly affects children and elderly adults, and thus does not seem to involve people who are active purchasers-consumers.

This review of studies on the subject highlights some of the limitations of using the term indiscriminately to explain consumer choices in general. The literature seems to show that feelings of "fear" or "disgust" towards the new in many cases reflect very specific ideological or value choices, which may cause the individual to take up positions in favor of environmentalism, animal welfare or ecology or simply because an individual is clinging to tradition. Thus, we can understand the reasons for avoiding or rejecting a food category only if we identify the consumer's underlying "food philosophy". Moreover, it is only in this way that we can circumvent avoidance and rejection. Confining ourselves to investigating food avoidance behavior could lead us to mistake what is in fact disdain or rebellion for fear. For this reason, our literature review will go into the details of some of these value positions, using other constructs linked to the type of diet chosen to investigate different consumer attitudes to genetically modified organisms (GMOs), cultured meat and edible insects.

\section{Processes behind Food Innovation: The Role of Research, Development and Market Orientation in Food Company Innovation and Consumer Demand}

Food innovation arises from the interaction of producers, retailers and consumers. Each of these actors brings his own set of requirements and goals, explicit or otherwise, generating highly complex multifactor processes that we will now summarize.

For successful companies, innovation is the key to combining long-term profitability, corporate growth and continuity if it can create stable or growing market demand $[10,13]$. In a broad sense, the "philosophy of Innovation" includes placing new or improved products and new services on the market, and introducing practices that oblige the company to review its production and organizational system [14]. In addition, it entails the co-construction of a shared lexicon and a system of values that resonates with the consumer's outlook. In fact, some products would have a large market in certain cultural settings, and no market at all in settings that are too far removed from the logic that produced 
them. If well managed, the set of all these variables enables companies to set themselves apart from the rest of their marketplace [15,16], increase competitiveness and reduce production costs [17].

What distinguishes the companies that are most successful in implementing the philosophy of innovation? Undoubtedly, these companies focus on research, development and market orientation [18]. However, the companies that invest large amounts in research and innovation are not necessary the most innovative [19]. According to Capitanio [7], Research and Development (R\&D) also hinges on the quality of human capital. The agri-food sector in particular requires a workforce with different skills and various kinds of human capital—called "inter-functional teams"—in order to innovate effectively $[10,20]$. Thus, companies' R\&D work cannot be assessed merely on the basis of their financial involvement [21]. Market orientation is also vital, viz. "the detection and fulfilment of unfilled needs and wants of potential customers using the skills, resources and competences of the company" [22]. The literature on market orientation argues that manufacturing companies' success is closely linked to being able to rely on the receptiveness of a large market and to the company's skill at satisfying its needs $[5,23,24]$. Though it is true that the growth of the agri-food sector is not always the result of technological implementation and innovation, its expansion makes it possible to test new products with less risk of failure [25]. For small and medium-sized enterprises, important factors involved in growth and innovation include the characteristics of the entrepreneur and cooperation [26], as well as the market power exercised by retailers $[27,28]$ thanks to networks between retailers, transformers and producers [29]. Through exchanges between retailer and consumer, a steady stream of information regarding the buyers' attitude towards the products placed on the market can be acquired, providing feedback whereby products can be adapted on the basis of consumer satisfaction. Consumer acceptance and willingness to try food innovations involve multiple dimensions, including the values connected to the food choice, the attitude towards specific products [30,31], expectations and economic considerations. Consumer expectations of product quality, sensory characteristics and production processes are crucial for product innovation [32]. Conflicting attitudes towards food innovations that have repercussions on the consumer's decision-making process can arise from the perceived relationship between risks and benefits and comparison with available alternatives [33]. On a food scene crowded with increasingly specific products, the consumer's final decision is often influenced by advertising. Media communication on the subject has always been an important tool for swaying public opinion. In this connection, several scholars have recently drawn attention to the so-called "crisis of authority, trust and responsibility" [34], arising worldwide as a result of the climate fomented by the media, which fuels anxiety about diet, health and food in particular, while at the same time generating a virtual space where anticonformist views can be expressed and strengthened [35-37]. The result is a "dietary cacophony", as Fischler, puts it, or in other words, a continual bombardment of conflicting messages that make it difficult to get our bearings and acquire structured information about what we eat [38]. Oftentimes, the celebrity quick-fix [39] takes on greater resonance in the media than the views of the scientific community. Some studies [40] suggest that scientific communication should avoid an over-polite style that may often be seen as unconvincing. Rather, it may be advisable to take more neutral or even aggressive attitudes, depending on whether the audience has no clear position on the matter, or tends to share the opinion the writer seeks to reinforce. This is a critically important finding, as it alludes to the risk of turning scientific information into a tool for manipulating consumers' emotions. Thus, careful attention should be given to determining the most appropriate ways to inform consumers and promote critical thinking on their part.

\section{Food Neophobia}

Recent literature [41] has addressed various degrees and types of "aversion to new foods", or food neophobia, which has been defined as the reluctance to eat, or the avoidance of, new or unknown foods. In the following pages, we will reconstruct the origins of the construct and the situations to which it can be applied. 
Rozin, the author who first described food neophobia, assumed it has an adaptive and evolutionary function. According to Rozin, human beings are omnivores and, therefore, eat many things. This means that they must use some strategy for avoiding poisonous foods, and preferring foods that will be beneficial to their health and growth [42,43]. In evolutionary terms, this function is fulfilled by neophobias from the moment a child begins to move independently of its parents. Food neophobia thus provides a means of guiding the child towards foods that are already familiar, and rejecting those that are new and might be dangerous. The aversion to bitterness, for example, due to hedonic neurobiological mechanisms present since birth [44], would help the child avoid eating potentially poisonous plants [45], and can persist until adulthood [46]. "Enemy food" may be rejected before tasting, on the basis of vision alone [47]. This has led to the idea of a very rigid visual coding of the food stimulus. If food is recognized as such because it is similar in shape and color to previous favorable food experiences, it is accepted; otherwise it is rejected. A parent's disapproval of food refusal by the child may be associated with the reaction of disgust with food, and that this may make the child even less willing to try new foods [48]. As many as eight to 15 repeated opportunities to sample an item may be needed to learn to accept a previously rejected food. With young children, one opportunity is enough to double the likelihood of consuming new food [49]. As children age, they tend to be less willing to accept new foods $[50,51]$. The most critical phase seems to be between two and six years [52]. Since repeated exposure can improve willingness to accept new foods, a number of intervention programs have been developed for schools. The "Food Dudes" program, for example, uses rewards, peer-modeling and repeated exposures to fruit and vegetables, two of the food categories that are most often rejected because of neophobia, to the detriment of health. These interventions seem to be effective in reducing food neophobia when deployed as early as possible and in any case not later than the age of nine years and, above all, if they last for at least six months [53,54]. Under these conditions, they seem able to instill a liking for fruit and vegetables [55-58].

There is also another type of behavior, especially among young children, which can sometimes be confused with food neophobia. This is as "picky/fussy" eating [59,60]: the rejection of a large proportion of familiar (as well as novel) foods, resulting in a habitual diet consisting of a particularly small variety of foods. However, as Taylor et al. wrote [61], "there is no single widely accepted definition of picky eating, although most definitions include an element of restricted intake of familiar foods, sometimes with a further degree of food neophobia". In addition, the behavior of super-tasters might overlap or be confused with that of picky/fussy eaters. The fact that many terms are used to describe the same phenomenon (picky, fussy, faddy or choosy eating) has led to the development of several different measures, making it even more difficult to compare data or establish where picky eating ends and food neophobia begins.

\subsection{Neophobia in Adults}

While food neophobia tends to disappear in adolescence, it can still be found in adults who restrict their diets to a few familiar products and refuse to eat anything else. As a result, they may be subject to nutritional deficiencies or social exclusion. Neophobia in adults appears to be influenced by different socio-demographic variables: urbanization is negatively correlated with neophobia, as is income and schooling [62]. Neophobia mostly affects older people and children, and is less common among young people, especially those who live in cities. It also tends to increase with age; the new generations have become accustomed to a greater variety of foods, both traditional and ethnic [63]. A neophobic component in old age can be due to several factors, including dental problems or gastrointestinal difficulties that can lead the elderly to avoid many foods.

The relationship with gender is not as clear. Some studies suggest that men are more neophobic than women, which could be linked to a wide range of cultural determinants, such as the time spent cooking [63], while other studies find no significant differences between the genders [62]. 


\subsection{The Role of Olfaction in Neophobia}

Neophobic children tend to selectively avoid fruit and vegetables [64]. It has been shown [65] that children develop high sensitivity to taste, and bitterness in particular has been negatively correlated with the amount and variety of consumed fruits and vegetables. Researchers believe that even in adults, the sense that is most strongly involved in the development of neophobia is smell [66].

Some studies have shown that people with food neophobia are less able than the general population to perceive odors (whether related to food or not) as pleasant and intense. They also seem to be less willing and interested in tasting new foods and much more uncertain about identifying unknown foods $[67,68]$. In addition, neophobic eaters generally expect new foods to be less palatable than familiar ones [69].

\subsection{Neophobia and Attitude towards New Foods}

Can the neophobia construct effectively explain resistance to new foods? Some research data indicates that the relationship between the two is problematic. For example, it has been shown that neophobia does not impact the choice of genetically modified products, or the choice of organic food [70], while it seems to be a negative predictor of willingness to taste non-traditional ethnic foods [71,72] and functional foods, i.e., foods that provide additional health benefits [73,74]. Two other studies found that higher levels of neophobia correlate with less willingness to eat healthy food (vegetables and fruit) in children [75] and in adolescents [76]. The question thus arises as to whether the resistance to accepting new foods is linked to certain food groups and not to newness as such. In other words, since resistance is shown towards fruit and vegetables in particular, it may not impact choices involving new foods. Rather, it may affect food categories that people are already used to eating, such as flour-based or highly processed foods. This contrasts with the findings of the survey conducted by Elorinne [77], which indicated that products of non-animal (i.e., vegetable) origin trigger lower levels of food neophobia than animal-based products. Food neophobia seems to be an extremely complex attitude. Its intensity tends to fluctuate during the life-span and is mediated by several variables $[68,78,79]$. As for its association with other psychological variables, it correlates with lower scores for sensation seeking [78] and trait anxiety [59], and is negatively correlated with openness to experience [80]. However, little is known about what contributes in the early stages to making a person neophobic, and what factors tend to maintain avoidance over time.

\subsection{What Do Neophobia Scores Actually Measure?}

Food neophobia is generally investigated using the Food Neophobia Scale (FNS) [81], which has been revised and adapted over the years [63] and translated into various languages. There is also a version for children adapted by Pliner [82]. This instrument investigates the degree of agreement or disagreement with items relating to the consumption of new foods or their avoidance. Specifically, it refers to the willingness to taste new, ethnic or unusual foods. However, it does not investigate the attitude, the emotional reaction and above all the conscious intentions or the reasons for choosing to avoid a food [83]. The FNS, however, is not the only instrument used to investigate unwillingness to try unfamiliar food. In their review, Damsbo-Svendsen [83] presented a qualitative and quantitative comparison of 13 different tools. They recommend that the researcher take great care in choosing the most appropriate instrument: "no instrument is suitable for measuring all aspects of neophobia" (p. 366). Each available instrument explores a different aspect, such as the attitude toward specific food categories (fruit and vegetables) or food situations, or foods produced with new technology. However, for some subcategories of novel food—such as genetically modified and functional foods - the relationship between the consumer's attitude and food neophobia may not be straightforward [67]. Furthermore, less conventional food choices, such as a vegan diet, can also result in high neophobia scores, as Elorinne's survey found [77]; this does not shed light on the reasoning behind the type of choice. The construct thus appears to be poorly defined, as it is very elastic and could encompass food 
philosophies that are very distant from each other. It would not be unreasonable to hypothesize that it refers more to choices relating to ethnic foods than to willingness to try unfamiliar foods. It should also be borne in mind that the philosophy of "short food supply chains" and locavorism could translate into resistance to new foods. Where such ethical-social considerations are the basic criterion for choosing certain specific food products over others, taking them into account would make it possible to predict consumer behavior more accurately. We also believe that the term "novel food" requires clarification. "Novel" can mean many things: (1) new compared to traditional cuisine, and thus exotic or ethnic food, (2) new compared to what the individual habitually eats, (3) new in the sense of being offered by a different brand, so that the individual tends to eat foods that are similar in their basic ingredients, but produced by other suppliers. Future research should also consider other variables that may play a role in explaining food conduct: it would be important to have a broader conceptualization of the implicit and explicit theories that lead people to engage in certain food behaviors rather than others. This would provide the agri-food industry with guidance regarding the product characteristics that can attract consumers, including those belonging to specific categories such as vegans, etc.

\section{Vegetarians' Attitudes to Insect Consumption-Neophobia or Respect for Life?}

Insect-based food has a low ecological impact and a high nutritional value, and is thus a potential sustainable alternative for human nutrition [30]. However, consumers' interest in insect-based products is weak [31], as Western food culture generally considers insects disgusting and inappropriate as food [30]. Vegetarians are an under-investigated but interesting population in relation to the consumption of insects. The vegetarian or vegan diets are based on different beliefs about animals that could influence attitudes towards consuming insects in a variety of ways [84,85]. People can fluctuate between different versions of the vegetarian diet. The vegan diet stands out among them, as it is more restrictive than a merely vegetarian diet, since it involves no animal derivatives of any kind [86], and usually entails rather strict ethical positions that are generally very strong in terms of personal identification [87-91]. In a study conducted in Finland, Elorinne et al. [90] examined groups with different diets (vegans, non-vegan vegetarians and omnivores) to compare the consumer's attitude towards insects as food, the influence exerted by social expectations (which the authors call the participants' "subjective norm") on insect consumption, participants' perceived control over their own eating behavior (the three factors underlying Ajzen's "Theory of Planned Behavior (TPB)") [92] and the level of food neophobia. Non-vegan vegetarians and omnivores shared similar values, while vegans differed significantly in almost all investigated constructs. In particular, the three groups interpreted the construct of "responsibility" very differently: vegans consider it very important and translate it into the choice of not eating insect-based food, whereas for omnivores and non-vegan vegetarians, responsibility coincides with environmental sustainability. Vegans also consider eating insects to be morally wrong, given their general tendency to consider meat consumption as more of a moral issue than one of sustainability, which leads them to be disgusted [87]. Vegans are also significantly more neophobic than non-vegan vegetarians and omnivores, a finding which the authors maintain may be partly explained by the fact that vegans' stricter moral attitude towards food of animal origin leads them to rule out eating insects more categorically than non-vegan vegetarians do. Unlike omnivores, none of the vegans mentioned disgust as a reason for refusing to consume insects despite their high neophobia scores, while all cited ethical reasons. This does not necessarily mean that disgust does not figure among the reasons, but it is not among the criteria that respondents considered relevant. As the literature testifies, vegans and non-vegan vegetarians tend to express feelings of disgust about meat consumption [90], but the reasons behind this disgust have not been scrutinized. As a result, a choice of an ethical-moral stamp has been confused with a food "phobia".

Among the general population, women are less likely than men to consume insects [93-95]. In the Finnish survey discussed here, highly educated city-dwelling women accounted for most of the sample, which may have influenced the results. However, as the authors point out, more information is needed about the dietarian identity profiles of consumer groups. Food conduct, as the authors 
emphasize, is not the outcome of an impromptu choice, simply linked to a particular situation. Food conduct is part of a "dietarian career" [77], i.e., dietary schemas that call for consistency [96] and are developed gradually over time, offering support and reinforcing a position that at first seems only exploratory. We believe that investigating this dietarian career can lay the foundations for arriving at the roots of food choices and understanding the principles they reflect.

\section{Synthetic Meat: Does Innovation Taste Better to Those Who Have Never Tasted It?}

Sensitivity to the suffering and killing of farm animals is increasing worldwide [87], as is the number of vegetarians. This, however, has not extinguished the desire to eat meat, particularly among higher-income consumers, who nevertheless also declare that they do not want to contribute to animal suffering [97]. From this perspective, cultivated meat is an excellent compromise for protecting animal welfare and allaying the ethical concerns of meat consumers [98]. Cultivated meat, also known as in-vitro, synthetic or "clean" meat, is another example of a novel food. It is produced from animal cells taken from a living animal and then grown in a laboratory environment with a nutrient serum [99-102]. Cultivated meat appears to be a more sustainable alternative to traditional meat: the first studies spoke of its potential to reduce land use by $99 \%$, water use by $96 \%$ and energy consumption by up to $45 \%$ [103]. More recent research has scaled back these performance estimates, finding that cultivated meat has a smaller land footprint than beef, and lower greenhouse gas emissions than poultry, pork and beef. This, however, comes at the price of a higher energy consumption than that is required for poultry and pork, and which is ultimately comparable to that necessary for beef [104]. The controlled production environment in which cultivated meat would be produced could provide opportunities for health and safety improvements, reducing the risk of diseases $[105,106]$. Nevertheless, some authors [100,107] point out that large-scale cell culture is never perfectly controlled and that unexpected biological mechanisms, such as the proliferation of cancer cells, may occur in production. That this is in fact a problem for the health of the consumer is still to be demonstrated, but the authors anticipate that it would be a very sensitive topic both for consumers and for legislators tasked with regulating meat cultivation.

Although cultivated meat is unlikely to appear on the market soon, companies are already investigating the profile of potentially interested consumers. Europeans appear to be divided, with at least half deeply suspicious of cultivated meat because it is unnatural $[108,109]$. It seems that providing information, particularly regarding environmental benefits, is important in order to encourage positive opinions among potential consumers [110]. The lack of familiarity with new technologies has been cited as a cause of distrust, uncertainty and concern about potential long-term negative consequences [110-112]. Both GMOs and cultured meat are categorized in this way, i.e., as technological innovations that arouse feelings of distrust and concern [110]. It would thus be important to reduce the false equivalences created by consumers, for example those that associate cultivated meat with GMOs [111].

Italy provides a good vantage point for investigating attitudes towards cultivated meat, as its food culture centers on traditional and natural foods [113]. In a study conducted by Mancini [114], participants were given information about cultivated meat's positive effects on the environment and showed a generally positive attitude. The best potential consumers were found to be young adults, with a high level of education; if previously informed, they were significantly more interested in buying than the other categories of participants. One of the most intriguing contradictions noted by the researchers is the fact that non-meat eaters had higher expectations about the taste of cultivated meat than meat eaters, even though the latter had expressed a higher intention to buy. Similar findings, with vegans and vegetarians more positive about cultivated meat but less interested in trying it than meat eaters, have also emerged from studies conducted in the United States [115]. The explanation offered for this apparently contradictory behavior is that these categories are not opposed to cultured meat but at the same time are not interested in consuming it. This would be perfectly in line with the choice of a vegan or vegetarian diet, and it thus might be appropriate to direct some strands of research 
to investigating people's motivations for making certain food choices, which are probably driven by a very strict internal logic even if they seem contradictory at first glance. If this is true, positive perceptions expressed about novel foods should not be simplistically interpreted as an indicator of their potential for commercial success [114].

\section{GMOs: Friends or Foes?}

GMOs are widely considered to be the future of food. As such, they have been the focus of public debate about their perceived risks, ranging from the reduction of biodiversity to long-term health consequences, such as toxicity or allergies [116,117]. Genetically Modified (GM) foods are derived from plants, animals or microorganisms whose genetic material (DNA) has been artificially modified, e.g., by introducing a gene from other organisms (viruses, bacteria, other plants and animals and even humans). Currently, such modifications are mostly applied in plants to improve their resistance to disease and/or tolerance to herbicides [118]. Because of the controversies both within the scientific community and in public discourse [118-122], many European countries have not yet formally authorized GM crops. According to Boccia [123], Europeans remain for the most part wary of GMOs, with wide regional variations. The highest percentages of opponents of GM foods are in Austria, Norway, Hungary $(70 \%)$, Cyprus (76\%), Italy (77\%) and Greece (81\%), followed by France and Denmark $(65 \%)$. The lowest proportions are in Portugal, Ireland, Spain and Finland [124]. These tendencies, however, are not stable over time, and the data is probably heavily influenced by the research design [125-131].

Popek et al. [132] published a study in 2017 on consumer opinions of genetically modified foods conducted in London and Warsaw. The study sought to determine whether there are cultural differences between the two countries, whose history in terms of GMO acceptance is quite dissimilar. Poland, which banned GMO crops in 2015, also restricts trade in genetically modified organisms. England is among the leaders in biotechnology, and GMOs boast the full support of the government, which sees them as an important economic resource. Contrary to expectations, the study's results were very homogeneous, suggesting that since all European consumers have access to global information sources, their attitudes towards certain phenomenon tend to converge. In both countries, city dwellers were similar in their attitudes and were more favorable to GMOs than their warier rural compatriots. This might merit further investigation. Most respondents agreed that longer shelf-life and resistance to extreme weather conditions are the main advantages of GMOs, while the most feared disadvantages were the unpredictable consequences of genetic modification, the production of species-specific toxins and food allergenicity. Other studies [133] found different concerns, including the fear of carcinogenic effects, environmental damage and the disappearance of natural products from the market. Overall, as many as $27.69 \%$ of respondents surveyed by Popek et al. had a negative attitude towards GM foods, while only $19.83 \%$ believed that GMOs would bring tangible benefits. The other respondents expressed no definite opinion.

The literature presents conflicting evidence about the role of information in changing attitudes towards GMOs. According to Scholderer and Frewer [53], none of the information strategies implemented in different European countries has succeeded in changing attitudes; indeed, it seems that they have negatively influenced the choice of products. Attitudes towards GMOs do not improve even when the mechanisms underlying the genetic modification are understood. It is clear that this is a particularly complex topic, and that consumer attitudes are probably also constructed on the basis of dimensions that research has not considered, which could involve social dynamics and values (i.e., in rural areas) that cannot be changed merely by providing cognitively relevant information. Yuan provides some innovative thoughts about using communication styles tailored to the audience to maximize the effectiveness of a positive message about GMOs. Focusing on the main trends of thought that are reinforced at the cultural and community level could provide more insight into the meanings underlying this generalized hostility. If this is indeed where the answer lies, measures intended to change individuals' opinions simply by providing information could be much less effective than hoped, as meanings are also socially constructed [134]. 


\section{Discussion}

It is clear from the studies analyzed here that the relationship between neophobia and technological innovation in the agri-food industry is much more complex and nuanced than it might seem. Using the concept of neophobia outside of its original clinical context to explain the motivation for consumer choices has many limitations. Consumer choices stem from systems of values that are rich in moral implications, often linked to sociopolitical and ecological-environmental considerations. Such judgments go far beyond what is thought to be the original adaptive value of neophobia. They cannot be reduced to the "picky eating" typical of children, given that food is also closely linked to identity and has a profound social and cultural meaning. The items in the Food Neophobia Scale $[63,81,82]$ investigate the consumption or avoidance of certain foods, referring in particular to new, ethnic or unusual foods. They do not attempt to tap aspects relating to attitude or emotional reaction. This makes it impossible to gain even a superficial grasp of the rationale behind the choice of avoidance, which could hinge on a wide range of reasons. Unconventional diets, such as the vegan diet, could result in high neophobia scores but are not situations to which the term neophobia applies, since they are choices based on ethical values and not simply on disgust toward specific foods. Moreover, what constitutes "novel foods" is poorly specified, as the term novel is used indiscriminately in the literature to denote food that is new compared to traditional cuisine and thus exotic or ethnic; new compared to what the individual habitually eats; or new in the sense of being offered by a different brand, similar in basic ingredients, but produced by other suppliers. We then examined some recent data on potential "novel foods", presenting several points that may be of interest in scrutinizing the meanings and motivations behind certain food choices.

Insects, which could provide an alternative source of nutritious proteins with a lower environmental cost than traditional animal protein sources, are a novelty to the European food scene. They are also particularly likely to elicit neophobic feelings, as they are considered exotic, "disgusting" and foreign to European food culture. In studies of the attitudes towards insect consumption of people with different eating styles (omnivores, vegans and non-vegan vegetarians), vegans were found to have the highest neophobia scores, not because they express disgust with insects, but out of consistency with their ethical objections to eating animals or animal derivatives. Much more favorable attitudes were held by non-vegan vegetarians, who are more concerned with environmental sustainability than with animal rights, and seem to feel that insects are not "proper" animals and can thus be eaten.

Lastly, consumers are divided between acceptance and rejection of synthetic meat. Though still utopian, synthetic meat is a solution that would address some of the most pressing problems associated with meat eating by eliminating animal exploitation and reducing the amount of energy and land needed to produce meat. Though cultivated meat's environmental benefits could be the key to swaying potential consumers' attitudes in its favor, this clashes with a general distrust of its "unnaturalness" and the potential consequences of the new technologies on health. It seems that the consumers with the greatest interest in buying are young, well-educated and knowledgeable about cultivated meat. In an apparent paradox, it has been found that vegetarians who were not interested in sampling cultivated meat had higher expectations about its taste than meat eaters who were in fact interested in buying. Future research could profitably address the motivations behind food choices, which prevent a positive perception from being transformed into an intention to buy, complicating the scene surrounding this novel food.

GMOs, long at the center of a series of controversies in the public discourse and in its legislative repercussions, still inspire conflicting opinions, some of which are uncompromisingly negative. A significant proportion of consumers in European capitals state that they are worried about GMOs' impact on health, biodiversity and the environment, though a majority has no firm opinion on the matter. This suggests that the information strategies implemented in previous decades have not had appreciable effects. It is doubtful that providing information can change attitudes to GMOs, and it may even be counterproductive. This may be because scholars often over-compartmentalize the motivations that then become attitudes: rather than being considered as part of an organic complex 
that also involves values and social dimensions, motivations are reduced to single affective or cognitive components. For example, it seems that where one lives could be a major predictor of GMO acceptance. Addressing this topic in future research would provide information whereby strategic marketing can be tailored to specific targets. Conceivably, this could improve the efficiency of a persuasion process aimed at increasing the acceptance of GMO technology.

\section{Conclusions}

This review of the recent situation in several European countries has explored several elements that are crucial for the development and innovation in the agri-food sector, both from the standpoint of the industry and from the consumer's perspective. In the latter connection, though consumer acceptance or rejection of a new food product hinges on a complex range of variables, three conclusions can be drawn that can assist companies that intend to introduce innovative practices or new products on the market:

(1) Resistance or refusal of new foods is rarely motivated by neophobia.

(2) More often, the rejection of a food choice should not be interpreted as an aversion to the specific product, or as selective and unmotivated avoidance of that product, but as an operational extension of a vision of the product filtered through the system of values embraced by the individual [134].

(3) In contemporary society, when many food alternatives are available, individuals discover and develop their own food identity, which is an important part of their self-identification and values (i.e., whether they see themselves as health-conscious, environmentalists, defenders of animal rights or traditional omnivores). This generates a stable identity profile that tends to be consistent and confirmed over time, in a dietarian career that progresses through successive steps.

Thus, we believe that future research should address the attitude towards new food products starting from an understanding of the food identity profile of the members of the population of interest. Only in this way will it be possible to tap the psychological variables linked to the system of values that drive food choices. While these values manifest themselves in the conduct of the individual, they are always in resonance with a food community, anchored to a series of typifications of food choices that individuals then tend to take as their own. A better understanding of these values would make it possible to determine whether innovations are consistent or compatible with the career profile to which the person tends to correspond. To be effective, information and marketing campaigns should be tailored to specific eater identity profile groups. An underinvestigated strategy for promoting a positive attitude to food innovation consists of investing in food ingredients or technologies that can be viewed favorably by specific food subgroups on the basis of the value system that their "food philosophy" is committed to safeguarding.

As this review has shown, today's food choices are highly fragmented as a result of individuals' differing ideological attitudes. Consequently, expecting to be able to introduce new foods that can be interesting or desirable across all consumer families seems outdated and unrealistic. Choosing the dietary group to be targeted by the innovation as the first step would seem to be a far more promising strategy.

Author Contributions: Conceptualization, review of the literature, investigation, writing-original draft preparation; writing - review and editing, E.F. and L.G.N.F.; supervision: E.F.

Funding: This research received no external funding.

Conflicts of Interest: The authors declare no conflict of interest.

\section{References}

1. Gerland, P.; Raftery, A.E.; Šev`cíková, H.; Li, N.; Gu, D.; Spoorenberg, T.; Alkema, L.; Fosdick, B.K.; Chunn, J.; Lalic, N.; et al. World population stabilization unlikely this century. Science 2014, 346, 234-237. [CrossRef] 
2. United Nations. World Population Prospects: The 2017 Revision, Key Findings and Advance Tables; ESA/P/WP/248; United Nations Department of Economic and Social Affairs/Population Division: New York, NY, USA, 2017.

3. Kummu, M.; Fader, M.; Gerten, D.; Guillaume, J.H.; Jalava, M.; Jägermeyr, J.; Pfister, S.; Porkka, M.; Siebert, S.; Varis, O. Bringing it all together: Linking measures to secure nations' food supply. Curr. Opin. Environ. Sustain. 2017, 29, 98-117. [CrossRef]

4. Springmann, M.; Clark, M.; Mason-D'Croz, D.; Wiebe, K.; Bodirsky, B.L.; Lassaletta, L.; de Vries, W.; Vermeulen, S.J.; Herrero, M.; Carlson, K.M.; et al. Options for keeping the food system within environmental limits. Nature 2018, 562, 519-525. [CrossRef] [PubMed]

5. Earle, M.D. Innovation in the food industry. Trends Food Sci. Technol. 1997, 8, 166-175. [CrossRef]

6. Mancini, P.; Marotta, G.; Nazzaro, C.; Simonetti, B. Consumer behaviour, obesity and social costs: The case of Italy. Int. J. Bus. Soc. 2015, 16, 295-324. [CrossRef]

7. Capitanio, F.; Coppola, A.; Pascucci, S. Product and process innovation in the Italian food industry. Agribusiness 2012, 26, 503-518. [CrossRef]

8. Marotta, G.; Nazzaro, C. Responsabilità sociale e creazione di valore nell'impresa agroalimentare: Nuove frontiere di ricerca. Econ. Agro-Aliment.-Food Econ. 2012, 1, 13-54.

9. Nazzaro, C.; Lerro, M.; Marotta, G. Assessing parental traits affecting children's food habits: An analysis of the determinants of responsible consumption. Agric. Food Econ. 2018, 6, 23-37. [CrossRef]

10. Roucan-Kane, M.; Gray, A.W.; Boehlje, M.D. Approaches for selecting product innovation projects in US food and agribusiness companies. Int. Food Agribus. Manag. Rev. 2011, 14, 51-68.

11. Nazzaro, C.; Lerro, M.; Stanco, M.; Marotta, G. Do consumers like food product innovation? An analysis of willingness to pay for innovative food attributes. Br. Food J. 2019, 121, 1413-1427. [CrossRef]

12. La Barbera, F.; Verneau, F.; Amato, M.; Grunert, K. Understanding Westerners' disgust for the eating of insects: The role of food neophobia and implicit associations. Food Qual. Prefer. 2018, 64, 120-125. [CrossRef]

13. Grunert, K.G.; van Trijp, H.C.M. Consumer-oriented new product development. Encycl. Agric. Food Syst. 2014, 2, 375-386.

14. Damanpour, F. Combinative effects of innovation types and organizational performance: A longitudinal study of service organizations. J. Manag. Stud. 2009, 46, 650-675. [CrossRef]

15. Baregheh, A.; Rowley, J.; Sambrook, S.; Davies, D. Innovation in food sector SMEs. J. Small Bus. Enterp. Dev. 2012, 19, 300-321. [CrossRef]

16. Karantininis, K.; Sauer, J.; Furtan, W.H. Innovation and integration in the agri-food industry. Food Policy 2010, 35, 112-120. [CrossRef]

17. Marotta, G.; Nazzaro, C.; Stanco, M. How the social responsibility creates value: Models of innovation in Italian pasta industry. Int. J. Glob. Small Bus. 2017, 9, 144-167. [CrossRef]

18. Grunert, K.G.; Harmsen, H.; Meulenberg, M.; Kuiper, E.; Ottowitz, T.; Declerck, F.; Traill, B.; Göransson, G. A framework for analysing innovation in the food sector. In Product and Process Innovation in the Food Sector; Traill, B., Grunert, K.G., Eds.; Blackie Academic: London, UK, 1997; pp. 1-37.

19. Bhattacharya, M.; Bloch, H. Determinants of innovation. Small Bus. Econ. 2004, 22, 155-162. [CrossRef]

20. Cooper, R.G.; Edgett, S.J.; Kleinschmidt, E.J. Benchmarking Best NPD practices-II. Res. Technol. Manag. 2004, 47, 50-59. [CrossRef]

21. Rama, R. Empirical study on sources of innovation in international food and beverage industry. Agribusiness 1996, 12, 123-134. [CrossRef]

22. Grunert, K.G.; Hartvig Larsen, H.L.; Madsen, T.K.; Baadsgaard, A. Market Orientation in Food and Agriculture; Kluwer Academic: Boston, MA, USA, 1996.

23. Borch, O.J.; Forsman, S. The competitive tools and capabilities of micro firms in the Nordic food sector: A comparative study. In the Food Sector in Transition: Nordic Research; Norwegian Agricultural Economics Research Institute: Oslo, Norway, 2000.

24. Steward-Knox, B.; Mitchell, P. What separates the winners from the losers in new product development. Trends Food Sci. Technol. 2003, 14, 58-64. [CrossRef]

25. Triguero, A.; Córcoles, D.; Cuerva, C.M. Differences in innovation between food and manufacturing firms: An analysis of persistence. Agribusiness 2013, 29, 273-292. [CrossRef]

26. Avermaete, T.; Viaene, J.; Morgan, E.J.; Pitts, E.; Crawford, N.; Mahon, D. Determinants of product and process innovation in small food manufacturing firms. Trends Food Sci. Technol. 2004, 15, 474-483. [CrossRef] 
27. Dobson, P.; Clarke, R.; Davies, S.; Waterson, M. Buyer power and its impact on competition in the food retail distribution sector of the European Union. J. Ind. Compet. Trade 2001, 1, 274-281. [CrossRef]

28. Weiss, H.R.; Wittkopp, A. Retailer concentration and product innovation in food manufacturing. Eur. Rev. Agric. Econ. 2005, 32, 219-244. [CrossRef]

29. Cox, H.; Mowatt, S.; Prevezer, M. New product development and product supply within a network setting: The chilled ready-meal industry in the UK. Ind. Innov. 2003, 10, 197-217. [CrossRef]

30. Fischer, C.B.; Steenbekkers, L.P.A.B. All insects are equal, but some insects are more equal than others. Br. Food J. 2018, 120, 852-863. [CrossRef]

31. Hartmann, C.; Siegrist, M. Consumer perception and behaviour regarding sustainable protein consumption: A systematic review. Trends Food Sci. Technol. 2017, 61, 11. [CrossRef]

32. Grunert, K.G. Consumer behaviour with regard to food innovations: Quality perception and decision-making. In Innovations in Agri-Food Systems-Product Quality and Consumer Acceptance; Jongen, W.M.F., Meulenberg, M.T.G., Eds.; Wageningen Academic Publishers: Wageningen, The Netherlands, 2005; pp. 57-82.

33. Dolgopolova, I.; Teuber, R.; Bruschi, V. Consumers' perceptions of functional foods: Trust and food neophobia in a cross-cultural context. Int. J. Consum. Stud. 2015, 39, 708-715. [CrossRef]

34. Belasco, W. Foreword. In Food Words: Essays in Culinary Culture; Jackson, P., Ed.; Routledge: London, UK, 2015; pp. 864-865. [CrossRef]

35. Jackson, P.; Watson, M.; Piper, N. Locating Anxiety in the Social: The Cultural Mediation of Food Fears. Eur. J. Cult. Stud. 2013, 16, 24-42. [CrossRef]

36. Levenstein, H. Fear of Food: A History of Why We Worry about What We Eat; University of Chicago Press: London, UK, 2012.

37. Rousseau, S. Food Media: Celebrity Chefs and the Politics of Everyday Interference; Berg: Oxford, UK, 2012.

38. Levenstein, H. Paradox of Plenty: A Social History of Eating in Modern America; University of California Press: Los Angeles, CA, USA, 2003.

39. Rousseau, S. The celebrity quick-fix: When good food meets bad science. Food Cult. Soc. 2015, 18, $265-287$. [CrossRef]

40. Yuan, S.; Ma, W.; Besley, J.C. Should Scientists Talk About GMOs Nicely? Exploring the Effects of Communication Styles, Source Expertise, and Preexisting Attitude. Sci. Commun. 2009, 41, 267-290. [CrossRef]

41. Kallas, Z.; Vitale, M.; Gil, J.M. Health innovation in patty products. the role of food neophobia in consumers' non-hypothetical willingness to pay, purchase intention and hedonic evaluation. Nutrients 2019, 11, 444. [CrossRef] [PubMed]

42. Rozin, E.; Rozin, P. Culinary themes and variations. Nat. Hist. 1981, 90, 6-14.

43. Rozin, P.; Vollmecke, T.A. Food likes and dislikes. Annu. Rev. Nutr. 1986, 6, 433-456. [CrossRef]

44. Steiner, J.E. Human facial expressions in response to taste and smell and stimulation. Adv. Child. Dev. Behav. 1979, 13, 257-295.

45. Glander, K.E. The impact of plant secondary compounds on primate feeding behavior. Yearb. Phys. Anthropol. 1982, 25, 1-18. [CrossRef]

46. Stein, L.J.; Nagai, H.; Nakagawa, M.; Beauchamp, G.K. Effects of repeated exposure and health-related information on hedonic evaluation and acceptance of a bitter beverage. Appetite 2003, 40, 119-129. [CrossRef]

47. Harris, G. Introducing the infant's first solid food. Br. Food J. 1993, 95, 7-10. [CrossRef]

48. Burgess, T.D.G.; Sales, S.M. Attitudinal effects of "mere exposure": A reevaluation. J. Exp. Soc. Psychol. 1971, 7,461-472. [CrossRef]

49. Birch, L.L.; Gunder, L.; Grimm-Thomas, K.; Laing, D.G. Infants' consumption of a new food enhances acceptance of similar foods. Appetite 1998, 30, 283-295. [CrossRef]

50. Cooke, L.J.; Carnell, S.; Wardle, J. Food neophobia and mealtime food consumption in 4-5 year old children. Int. J. Behav. Nutr. Phys. Act. 2006, 3, 14-19. [CrossRef] [PubMed]

51. Wardle, J.; Cooke, L.J.; Gibson, E.L.; Sapochnik, M.; Sheiham, A.; Lawson, M. Increasing children's acceptance of vegetables: A randomised trial of parent-led exposure. Appetite 2003, 40, 155-162. [CrossRef]

52. Cooke, L.; Wardle, J.; Gibson, E.L. Relationship between parental report of food neophobia and everyday food consumption in 2-6-year-old children. Appetite 2003, 41, 205-206. [CrossRef] 
53. Scholderer, J.; Frewer, L.J. The biotechnology communication paradox: Experimental evidence and the need for a new strategy. J. Consum. Policy 2003, 26, 125-127. [CrossRef]

54. Kronberger, N. Moralities We Live by: Moral Focusing in the Context of Technological Change. In Meaning in Action; Sugiman, T., Gergen, K.J., Wagner, W., Yamada, Y., Eds.; Springer: Tokyo, Japan, 2008.

55. Laureati, M.; Bergamaschi, V.; Pagliarini, E. School-based intervention with children. Peer-modeling, reward and repeated exposure reduce food neophobia and increase liking of fruits and vegetables. Appetite 2014, 83, 26-32. [CrossRef]

56. Faccio, E.; Costa, N.; Losasso, C.; Cappa, V.; Mantovani, C.; Cibin, V.; Andrighetto, I.; Ricci, A. What programs work to promote health for children? Exploring beliefs on microorganisms and on food safety control behavior in primary schools. Food Control. 2013, 33, 320-329. [CrossRef]

57. Faccio, E.; Costa, N.; Losasso, C.; Barrucci, F.; Mantovani, C.; Cibin, V.; Andrighetto, I.; Ricci, A. Drawing instead of answering to evaluate the effectiveness of food safety programmes in primary school. Health Educ. J. 2017, 76, 15-28. [CrossRef]

58. Losasso, C.; Cappa, V.; Cibin, V.; Mantovani, C.; Costa, N.; Faccio, E.; Andrighetto, I.; Ricci, A. Food safety and hygiene lessons in the primary school: Implications for risk-reduction behaviors. Foodborne Pathog. Dis. 2014, 11, 68-74. [CrossRef]

59. Dovey, T.M.; Staples, P.A.; Leigh Gibson, E.; Halford, J.C.G. Food neophobia and 'picky/fussy' eating in children: A review. Appetite 2008, 50, 181-193. [CrossRef]

60. Lafraire, J.; Camille Rioux, C.; Giboreau, A.; Picard, D. Food rejections in children: Cognitive and social/environmental factors involved in food neophobia and picky/fussy eating behavior. Appetite 2016, 96, 347-357. [CrossRef]

61. Taylor, C.M.; Wernimont, S.M.; Northstone, K.; Emmett, P.M. Picky/fussy eating in children: Review of definitions, assessment, prevalence and dietary intakes. Appetite 2015, 95, 349-359. [CrossRef] [PubMed]

62. Meiselman, H.L.; King, S.C.; Gillette, M. The demographics of neophobia in a large commercial US sample. Food Qual. Prefer. 2010, 21, 893-897. [CrossRef]

63. Siegrist, M.; Hartmann, C.; Keller, C. Antecedents of food neophobia and its association with eating behavior and food choices. Food Qual. Prefer. 2013, 30, 293-298. [CrossRef]

64. Wardle, J.; Cooke, L. Genetic and environmental determinants of children's food preferences. Br. J. Nutr. 2008, 99, 15-21. [CrossRef] [PubMed]

65. Coulthard, H.; Blissett, J. Fruit and vegetable consumption in children and their mothers. Moderating effects of child sensory sensitivity. Appetite 2009, 52, 410-415. [CrossRef] [PubMed]

66. Demattè, M.L.; Endrizzi, I.; Gasperi, F. Food neophobia and its relation with olfaction. Front. Psychol. 2014, 5, 127. [CrossRef]

67. Tuorila, H.M.; Mustonen, S. Reluctant trying of an unfamiliar food induces negative affection for the food. Appetite 2010, 54, 418-421. [CrossRef]

68. Frank, R.A.; Raudenbush, B. Individual differences in approach to novelty: The case of human food neophobia. In Viewing Psychology as a Whole: The Integrative Science of William; Dember, N., Hoffman, R.R., Sherrick, M.F., Warm, J.S., Eds.; American Psychological Association: Washington, DC, USA, 1998; pp. 227-245.

69. Pliner, P.; Pelchat, M.L.; Grabski, M. Reduction of neophobia in humans by exposure to novel foods. Appetite 1993, 20, 111-123. [CrossRef]

70. Backstrom, A.; Pirttila-Backman, A.M.; Tuorila, H. Willingness to try new foods as predicted by social representations and attitude and trait scales. Appetite 2004, 43, 75-83. [CrossRef]

71. Choe, J.Y.; Cho, M.S. Food neophobia and willingness to try non-traditional foods for Koreans. Food Qual. Prefer. 2011, 22, 671-677. [CrossRef]

72. D'Antuono, L.F.; Bignami, C. Perception of typical Ukrainian foods among an Italian population. Food Qual. Prefer. 2012, 25, 1-8. [CrossRef]

73. Siegrist, M.; Stampfli, N.; Kastenholz, H. Consumers' willingness to buy functional foods. The influence of carrier, benefit and trust. Appetite 2008, 51, 526-529. [CrossRef] [PubMed]

74. Urala, N.; Lahteenmaki, L. Consumers' changing attitudes towards functional foods. Food Qual. Prefer. 2007, 18, 1-12. [CrossRef]

75. Falciglia, G.A.; Couch, S.C.; Gribble, L.S.; Pabst, S.M.; Frank, R. Food neophobia in childhood affects dietary variety. J. Am. Diet. Assoc. 2000, 100, 1474. [CrossRef] 
76. Mustonen, S.; Oerlemans, P.; Tuorila, H. Familiarity with and affective responses to foods in 8-11-year-old children. The role of food neophobia and parental education. Appetite 2012, 58, 777-780. [CrossRef]

77. Elorinne, A.; Niva, M.; Vartiainen, O.; Väisänen, P. Insect consumption attitudes among vegans, non-vegan vegetarians, and omnivores. Nutrients 2019, 11, 292. [CrossRef]

78. Otis, L.P. Factors influencing the willingness to taste unusual foods. Psychol. Rep. 1984, 54, 739-745. [CrossRef]

79. Howard, A.J.; Mallan, K.M.; Byrne, R.; Magarey, A.; Daniels, L.A. Toddlers' food preferences. The impact of novel food exposure, maternal preferences and food neophobia. Appetite 2012, 59, 818-825. [CrossRef]

80. Knaapila, A.; Silventoinen, K.; Broms, U.; Rose, R.J.; Perola, M.; Kaprio, J.; Tuorila, H.M. Food neophobia in young adults: Genetic architecture and relation to personality, pleasantness and use frequency of foods, and Body Mass Index. A twin study. Behav. Genet. 2011, 41, 512-521. [CrossRef]

81. Pliner, P.; Hobden, K. Development of a scale to measure the trait of food neophobia in humans. Appetite 1992, 19, 105-120. [CrossRef]

82. Pliner, P. Development of measures of food neophobia in children. Appetite 1994, 23, 147-163. [CrossRef] [PubMed]

83. Damsbo-Svendsen, M.; Bom Frøst, M.; Olsen, A. A review of instruments developed to measure food neophobia. Appetite 2017, 113, 358-367. [CrossRef] [PubMed]

84. Fischer, B. Bugging the strict vegan. J. Agric. Environ. Ethics 2016, 29, 255-263. [CrossRef]

85. Tuorila, H.; Lahteenmaki, L.; Pohjalainen, L.; Lotti, L. Food neophobia among the Finns and related responses to familiar and unfamiliar foods. Food Qual. Prefer. 2001, 12, 29-37. [CrossRef]

86. House, J. Are insects animals? The ethical position of insects in Dutch vegetarian diets. In Ethical Vegetarianism and Veganism; Linzey, A., Linzey, C., Eds.; Routledge: London, UK, 2019.

87. Melina, V.; Craig, W.; Levin, S. Position of the academy of nutrition and dietetics: Vegetarian diets. J. Acad. Nutr. Diet. 2016, 116, 1970-1980. [CrossRef]

88. Ruby, M.B. Vegetarianism. A blossoming field of study. Appetite 2012, 58, 141-150. [CrossRef]

89. Fox, N.; Ward, K. Health, ethics and environment: A qualitative study of vegetarian motivations. Appetite 2008, 50, 422-429. [CrossRef]

90. Radnitz, C.; Beezhold, B.; DiMatteo, J. Investigation of lifestyle choices of individuals following a vegan diet for health and ethical reasons. Appetite 2015, 90, 31-36. [CrossRef]

91. Elorinne, A.; Kantola, M.; Voutilainen, S.; Laakso, J. Veganism as a choice: Experiences and food strategies in transitioning to a vegan diet. In Food Futures: Ethics, Science and Culture; Wageningen Academic Publisher: Wageningen, The Netherlands, 2016.

92. Rosenfeld, D.L. A comparison of dietarian identity profiles between vegetarians and vegans. Food Qual. Prefer. 2019, 72, 40-44. [CrossRef]

93. Ajzen, I. The theory of planned behavior. Organ. Behav. Hum. Decis. Process. 1991, 50, 179-211. [CrossRef]

94. Tan, H.S.G.; van den Berg, E.; Stieger, M. The influence of product preparation familiarity and individual traits on the consumer acceptance of insects as food. Food Qual. Prefer. 2016, 48, 222-231. [CrossRef]

95. Cicatiello, C.; De Rosa, B.; Franco, S.; Lacetera, N. Consumer approach to insects as food: Barriers and potential for consumption in Italy. Br. Food J. 2016, 118, 2271-2286. [CrossRef]

96. Verbeke, W. Profiling consumers who are ready to adopt insects as a meat substitute in a Western society. Food Qual. Prefer. 2015, 39, 147-155. [CrossRef]

97. Rosenfeld, D.L.; Burrow, A.L. Development and validation of the dietarian identity questionnaire: Assessing self-perceptions of animal-product consumption. Appetite 2018, 127, 182-194. [CrossRef]

98. Hopkins, P.D.; Dacey, A. Vegetarian meat: Could technology save animals and satisfy meat eaters? J. Agric. Environ. Ethics 2008, 21, 579-596. [CrossRef]

99. Bartholet, J. Inside the meat lab. Sci. Am. 2011, 304, 64-69. [CrossRef]

100. Edelman, P.D.; McFarland, D.C.; Mironov, V.A.; Matheny, J.G. Commentary: In vitro-cultured meat production. Tissue Eng. 2005, 11, 659-662. [CrossRef]

101. Bhat, Z.F.; Fayaz, H. Prospectus of cultured meat-Advancing meat alternatives. J. Food Sci. Technol. 2011, 48, 125-140. [CrossRef]

102. Post, M.J. Cultured meat from stem cells: Challenges and prospects. Meat Sci. 2012, 92, 297-301. [CrossRef]

103. Moritz, M.S.; Verbruggen, S.E.; Post, M.J. Alternatives for large-scale production of cultured beef: A review. J. Integr. Agric. 2015, 14, 208-216. [CrossRef] 
104. Tuomisto, H.L.; Teixeira de Mattos, M.J. Environmental Impacts of Cultured Meat Production. Environ. Sci. Technol. 2011, 45, 6117-6123. [CrossRef] [PubMed]

105. Mattick, C.S.; Landis, A.E.; Allenby, B.R.; Genovese, N.J. Anticipatory life cycle analysis of in vitro biomass cultivation for cultured meat production in the United States. Environ. Sci. Technol. 2015, 49, 11941-11949. [CrossRef] [PubMed]

106. Datar, I.; Betti, M. Possibilities for an in vitro meat production system. Innov. Food Sci. Emerg. Technol. 2010, 11, 13-22. [CrossRef]

107. Hocquette, J.F.; Mainsant, P.; Daudin, J.D.; Cassar Malek, I.; Rémond, D.; Doreau, M.; Sans, P.; Bauchart, D.; Agabriel, J.; Verbecke, W.; et al. Will meat be produced in vitro in the future? INRA Prod. Anim. 2013, 26, 363-374.

108. Hocquette, J.F. Is in vitro meat the solution for the future? Meat Sci. 2016, 120, 167-176. [CrossRef] [PubMed]

109. Eurobarometer, S. Social values, science and technology. Eurobarom. Spec. Rep. 2005, 225.

110. Verbeke, W.; Marcu, A.; Rutsaert, P.; Gaspar, R.; Seibt, B.; Fletcher, D.; Barnett, J. ‘Would you eat cultured meat?': Consumers' reactions and attitude formation in Belgium, Portugal and the United Kigdom. Meat Sci. 2015, 102, 49-58. [CrossRef]

111. Verbeke, W.; Sans, P.; Van Loo, E. Challenges and prospects for consumer acceptance of cultured meat. J. Integr. Agric. 2015, 14, 285-294. [CrossRef]

112. Marcu, A.; Gaspar, R.; Rutsaert, P.; Seibt, B.; Fletcher, D.; Verbeke, W.; Barnett, J. Analogies, metaphors, and wondering about the future: Lay sense-making around synthetic meat. Public Underst. Sci. 2015, 24, 547-562. [CrossRef]

113. Siegrist, M.; Sütterlin, B. Importance of perceived naturalness for acceptance of food additives and cultured meat. Appetite 2017, 113, 320-326. [CrossRef]

114. Lazzaroni, C.; Iacurto, M.; Vincenti, F.; Biagini, D. Consumer Attitudes to Food Quality Products of Animal Origin in Italy. In Consumer Attitudes to Food Quality Products. Emphasis on Southern Europe; Klopčič, M., Kuipers, A., Hocquette, J.F., Eds.; Wageningen Academic Publishers: Wageningen, The Netherlands, 2013; pp. 83-96.

115. Mancini, M.C.; Antonioli, F. Exploring consumers' attitude towards cultured meat in Italy. Meat Sci. 2019, 150, 101-110. [CrossRef] [PubMed]

116. Wilks, M.; Phillips, C.J. Attitudes to in vitro meat: A survey of potential consumers in the United States. PLoS ONE 2017, 12, e0171904. [CrossRef] [PubMed]

117. Bongoni, R. East versus West: Acceptance of GM foods by European and Asian Consumers. Nutr. Food Sci. 2016, 46, 628-636. [CrossRef]

118. Davis, L.A. Genetically Engineered Crops. Engineering 2016, 2, 268-269. [CrossRef]

119. Domingo, J.L. Safety assessment of GM plants: An updated review of the scientific literature. Food Chem. Toxicol. 2016, 95, 12-18. [CrossRef]

120. López, O.A.M.; Pérez, E.F.; Fuentes, E.E.S.; Luna-Espinoza, I.; Cuevas, F.A. Perceptions and attitudes of the Mexican urban population towards genetically modified organisms. Br. Food J. 2016, 118, 2873-2892. [CrossRef]

121. Sarno, V.; Manzo, R.M. Italian companies' attitude towards GM crops. Nutr. Food Sci. 2016, 46, 685-694. [CrossRef]

122. Grunert, K.G.; Bredahl, L.; Scholderer, J. Four questions on European consumers' attitudes toward the use of genetic modification in food production. Innov. Food Sci. Emerg. Technol. 2003, 4, 435-445. [CrossRef]

123. Boccia, F. Consumer perception: An analysis on second generation genetically modified foods. Nutr. Food Sci. 2016, 46, 637-646. [CrossRef]

124. Vlontzos, G.; Duquenne, M.N. To eat or not to eat? The case of genetically modified (GM) food. Nutr. Food Sci. 2016, 46, 647-658. [CrossRef]

125. Gaskell, G.; Allum, N.; Stares, S. A Report to the EC Directorate General for Research from the Project "Life Sciences in European Society". Eur. Biotechnol. 2002 2003, 58.

126. O'Connor, E.; Cowan, C.; Williams, G.; O'Connell, J.; Boland, M.P. Irish consumer acceptance of a hypothetical second-generation GM yogurt product. Food Qual. Prefer. 2006, 17, 400-411. 
127. Bech-Larsen, T.; Grunert, K.G. Can health benefits break down Nordic consumers' rejection of genetically modified foods? A conjoint study of Danish, Norwegian, Swedish and Finnish consumers preferences for hard cheese. In Proceedings of the ANZMAC 2000 Visionary Marketing for the 21st Century Conference, Griffith, Australia, 28 November-1 December 2000; pp. 78-82.

128. Honkanen, P.; Verplanken, B. Understanding attitudes toward genetically modified food: the role of values and attitudes strength. J. Consum. Policy 2004, 27, 401-420. [CrossRef]

129. Szczurowska, T. "Poles on biotechnology and genetic engineering", TNS OBOP, Plant Breeding and Acclimatization Institute, Radzikow. 2015. Available online: www.ihor.edu.pl (accessed on 29 November 2015).

130. Janik-Janiec, B.; Twordowski, T. “The social acceptance of Biotechnology in 2003 Europe and Poland”, Polska Federacja Biotechnologii (PFB). 2003. Available online: www.pfb.p.lodz.pl (accessed on 29 November 2015).

131. Grunert, K.G.; Lähteenmäki, L.; Nielsen, N.A.; Poulsen, J.B.; Ueland, O.; Ström, A. Consumer perceptions of food products involving genetic modification: results from a qualitative study in four Nordic countries. Food Qual. Prefer. 2001, 12, 527-542. [CrossRef]

132. Popek, S.; Halagarda, M. Genetically modified foods: Consumer awareness, opinions and attitudes in selected EU countries. Int. J. Consum. Stud. 2017, 41, 325-332. [CrossRef]

133. Tas, M.; Balci, M.; Yüksel, A.; Yesilçubuk, N.S. Consumer awareness, perception and attitudes towards genetically modified foods in Turkey. Br. Food J. 2015, 117, 1426-1439. [CrossRef]

134. Castiglioni, M.; Faccio, E.; Veronese, G.; Mosolo, A.P.; Bell, R.C. Disturbi alimentari e costruzione del significato. Psicol. Della Salut. 2011, 3, 5-28. [CrossRef]

(C) 2019 by the authors. Licensee MDPI, Basel, Switzerland. This article is an open access article distributed under the terms and conditions of the Creative Commons Attribution (CC BY) license (http://creativecommons.org/licenses/by/4.0/). 